\title{
MODEL PENANGANAN KERUSAKAN TERUMBU KARANG DI KEPULAUAN SERIBU DKI JAKARTA
}

\author{
Samadi \\ Dosen Jurusan Geografi FIS UNJ \\ Email: adinote@gmail.com
}

\begin{abstract}
ABSTRAK
Tujuan penelitian ini adalah untuk mengkonstruksi model penanganan kerusakan terumbu karang di perairan Kepulauan Seribu DKI Jakarta khususnya di Pulau Pari selama Bulan Agustus hingga minggu pertama Bulan Oktober tahun 2013. Metode penelitian yang digunakan adalah metode kualitatif melalui prosedur studi pendahuluan, observasi lapangan, dan pengamatan langsung di lapangan terutama kondisi fisik, serta kegiatan wawancara mendalam yang dlanjutkan dengan focus groups discussion. Populasi pada penelitian ini terdiri dari biofisik lingkungan (terumbu karang) dan sosial (masyarakat), sedangkan pengambilan sampel pada terumbu karang menggunakan teknik area dan untuk sampel sosial menggunakan purpossive.Teknik pengumpulan data biotik terumbu karang menggunakan metoda Line Intercept Transect. Sedangkan pada faktor abiotik untuk analisis gugus terumbu karang secara makro ditekankan pada pemetaan habitat gugusan karang di sekitar perairan. Adapun teknik analisis data menggunakan metode Triangulasi. Hasil penelitian menunjukkan bahwa: 1) Kondisi terumbu karang di perairan Pulau Pari masih dalam kondisi baik, 2) Masih dominannya mata pencaharian penduduk sebagai nelayan, 3) Formula mediasi konflik sosial-ekonomipariwisata dalam penanganan kerusakan terumbu karang khususnya di Pulau Pari Kepulauan Seribu perlu memperhatikan tiga pilar utama yaitu: organisasi lokal maupun luar pulau, partisipasi wisatawan terhadap pelestarian terumbu karang, serta pemberdayaan bagi warga lokal, pendatang maupun para wisatawan, dan 4) Upaya pengembangan model penanganan kerusakan terumbu karang lebih ditekankan pada aspek-aspek penguatan organisasi lokal yang semakin tangguh. Organisasi lokal ini tentunya dibangun atas dasar kesepahaman terhadap faktor-faktor perubahan yang diinginkan dan atau yang tidak diinginkan dan itu telah disepakati. Penguatan organisasi lokal tentunya harus memberikan teladan yang baik terhadap pendatang terkait upaya pelestarian lingkungan khususnya penyelamatan dan pelestarian terumbu karang.

Kata kunci: Model penanganan kerusakan terumbu karang, Kepulauan Seribu, DKI Jakarta
\end{abstract}

\section{PENDAHULUAN}

Benturan kepentingan dan keinginan serta ego sektoral dalam pengelolaan kawasan pesisir dan pulau-pulau kecil tidak terlepas dari belum adanya pembagian kewenangan yang jelas dan tegas baik antara Pemerintah Pusat dengan Pemerintah Daerah maupun antara instansi yang ada, terutama berkaitan dengan kewenangan terhadap fungsi (1) perijinan, (2) perencanaan, dan (3) fungsi pengawasan dan pengendalian; dimana ketiga fungsi tersebut cenderung berjalan sendiri-sendiri tanpa koordinasi dengan instansi lain sehingga seringkali terjadi overlapping tugas dan kewenangan dan duplikasi kebijakan sehinga program kerja yang dijalankan tidak berjalan secara efektif dan efisien yang mengena pada sasaran pembangunan. Badan Perencanan Pembangunan Daerah / Kabupaten (Bappeda / Bapekab) belum dimanfaatkan dan bekerja secara optimal sebagai lembaga koordinasi yang bertugas mengkoordinir kegiatan pembangunan mulai dari tahapan perencanaan sampai pelaksanaan dan evaluasi dari beberapa 
instansi yang berperan di kawasan pesisir dan pulau-pulau kecil.

Keutuhan daya dukung lingkungan pesisir sangat dibutuhkan guna pengembangan ilmu pengetahuan, pendidikan, dan penelitian serta kawasan lindung dan wisata bahari disamping kemungkinan kedepannya untuk permukiman. Seperti halnya di kawasan perairan Pulau Pari Kepulauan Seribu, kondisi terumbu karang di Pulau Pari Utama dan Pulau Pari Kudus relatif masih dalam kondisi baik, dan rerata kerapatan lamun rata-rata cukup tersebar tegakkannya di Utara dan Selatan pulau. Namun demikian, kondisinya saat ini terus mengalami penurunan jumlah dan sebarannya. Dari data yang dikumpulkan melalui beberapa sumber di lapangan, tercatat bahwa jumlah karang di Pulau Pari sejak tahun 1985 hingga tahun 2008 terus mengalami penurunan.

Makin menurunnya jumlah maupun sebaran terumbu karang di atas terkadang di cap sebagai "salahnya" masyarakat dalam mengelola sumberdaya, namun tidak mengkaji kemungkinan tumpang tindih tugas, fungsi dan kewenangan aparatur pemerintah dalam konteks pengelolaan secara terpadu. Pelimpahan kewenangan dari Pemerintah Propinsi ke Kabupaten Administratif Kepulauan Seribu hanya terbatas pada wilayah administrasi saja dan belum pada kewenangan secara menyeluruh sehingga hal ini menjadi hambatan dalam pengelolaan pembangunan secara keseluruhan.

Konflik lingkungan diantaranya telah terjadi sehubungan dengan adanya permasalahan berkurangnya jumlah dan sebaran terumbu karang. Seperti pada kasus pengambilan terumbu karang di banyak pulau kecil, sama-sama dipicu oleh adanya upaya pembangunan di pinggir pantai seperti permukiman dan atau obyek wisata (dermaga, cottage, rumah makan, dan lain-lain).

Bangunan-bangunan di tepi pantai yang menjorok ke laut tersebut menyebabkan perubahan hilangnya tegakkan mangrove dan pengambilan terumbu karang untuk pondasi bangunan, maupun dampak yang lebih luas seperti perubahan pola arus dan gelombang, yang pada akhirnya menimbulkan erosi dan sedimentasi pada wilayah pantai di sekitarnya. Kasus-kasus kerusakan pantai ini kemudian memunculkan konflik baik antara pemerintah, industri (pariwisata) dan dengan masyarakat lokal di sekitar pantai seperti halnya pada konflik kegiatan penanganan Penanganan Kerusakan Terumbu Karang di Kepulauan Seribu DKI Jakarta.

\section{METODOLOGI PENELITIAN}

Metode penelitian yang digunakan adalah metode kualitatif. Metode kualitatif dalam penelitian ini merupakan kajian analitik terhadap data dan informasi meliputi hasil studi pendahuluan, observasi di lapangan, dan pengamatan langsung di lapangan terutama kondisi fisik, serta kegiatan Focus Group Discussions untuk mengetahui kebutuhan (Needs) dan keinginan (wants) masyarakat. Penelitian ini dilaksanakan di kawasan perairan Kepulauan Seribu - DKI Jakarta, khususnya di Pulau Pari selama bulan Agustus hingga minggu pertama bulan Oktober tahun 2013.

Penelitian ini menggunakan 2 (dua) variabel besar yaitu variabel biofisik lingkungan (biotik) dan variabel sosial (abiotik). Populasi penelitian terdiri dari variabel biofisik lingkungan (terumbu karang). Sedangkan populasi dari variabel sosial adalah masyarakat di Kepulauan Seribu DKI Jakarta. Sampel penelitian pada terumbu karang menggunakan area sampling yang ditentukan berdasarkan kedalaman perairan 5-7 meter untuk setiap stasiun sampling. Sedangkan untuk pengambilan sampel sosial menggunakan purpossive sampling yang difokuskan pada tokoh dan pemuka masyarakat, guru dan kepala sekolah setempat, serta pejabat pemerintah terkait dalam pengembangan dan pengelolaan sumberdaya alam dan lingkungan di Kepulauan Seribu, Kabupaten Administratif Kepulauan Seribu DKI Jakarta. Data dikumpulkan melalui strategi pengumpulan data berdasarkan beberapa faktor terkait, yaitu: 1. Faktor Biotik 
Dalam kajian faktor biotik, metoda transek diterapkan untuk memperoleh data dan informasi secara kuantitatif terhadap ekosistim terumbu karang. Pengamatan terumbu karang dalam penelitian ini menggunakan metode Line Intercept Transect/LIT. Posisi pengamatan diambil menggunakan GPS -Global Positioning System.

2. Faktor Abiotik

a. Gugus terumbu karang secara makro

Kajian faktor abiotik dalam penelitian ini ditekankan pada pemetaan habitat gugusan karang di sekitar perairan.

b. Kondisi sosial-ekonomi

Hal-hal yang ditanyakan dalam wawancara antara lain adalah kondisi umum masyarakat (kisaran umur, jenis kelamin, status pernikahan, jumlah anak, tingkat pendidikan dan penghasilan dalam 1 bulan), persepsi masyarakat tentang bentuk perubahan yang mereka rasakan selama ini, dan hal-hal yang menyebabkan perubahan lingkungan, persepsi masyarakat tentang hal-hal yang mereka inginkan dan yang tidak mereka inginkan, serta persepsi masyarakat tentang bentuk-bentuk pengembangan.
Instrumen yang digunakan dalam penelitian ini adalah lembar observasi lapang untuk melaporkan hasil pengamatan dan penghitungan koloni terumbu karang dari hasil pengukuran melalui metode transek. Kemudian pada lingkup data sosial-ekonomi menggunakan lembar panduan serta format diskusi dalam Focus Group Discussion. Adapun teknik analisis data menggunakan metode Triangulasi.

HASIL DAN PEMBAHASAN

Data geografis-sosial-ekonomi-lingkungan

Secara geografis kawasan Pulau Pari terletak antara $05^{\circ} 50^{\prime}$ hingga $05^{\circ} 52^{\prime}$ Lintang Selatan dan $106^{\circ} 34^{\prime}$ sampai $106^{\circ} 38^{\prime}$ Bujur Timur. Daerah ini terletak di Laut Jawa, tepatnya di sebelah Utara DKI Jakarta dan Tangerang. Secara administrasi Pulau Pari termasuk Kelurahan Pulau Tidung, Kecamatan Kepulauan Seribu Selatan, Kabupaten Administratif Kepulauan Seribu, Provinsi DKI Jakarta.

Kaitan aspek sosial-demografis yang dilaporkan dalam penelitian ini adalah aspekaspek kependudukan (jumlah penduduk), jenis mata pencaharian dan tingkat pendapatan, tingkat pendidikan dan sarana pendidikan.

Tabel 1. Mata Pencaharian Responden

\begin{tabular}{lcc}
\hline \multicolumn{1}{c}{ Mata Pencaharian } & Jumlah & Persentase (\%) \\
\hline Nelayan & 46 & 63,0 \\
Pegawai Swasta & 1 & 1,4 \\
Pegawai Negeri & 4 & 5,5 \\
Wiraswasta & 11 & 15,1 \\
Lainnya & 11 & 15,1 \\
\hline Total & 73 & 100,0 \\
\hline
\end{tabular}

Sumber: data lapang, 2013

Jumlah penduduk Pulau Pari yang berada di RW 04 Kelurahan Pulau Pari, yang terdiri dari 4 (empat) RT tercatat berjumlah 917 jiwa dengan jumlah Kepala Keluarga 265 KK. Penduduk di lokasi penelitian bermata pencaharian sebagai nelayan $(63,0 \%)$, kemudian wiraswasta $(15,1 \%)$, guide wisatawan dan buruh nelayan $(15,1 \%)$, Pegawai Negeri Sipil $(5,5 \%)$, serta Pegawai Swasta $(1,4 \%)$. Untuk diketahui, sebagaian masyarakat yang juga responden penelitian mengaku pernah menekuni usaha budidaya rumput laut sehingga mayoritas penduduk Pulau Pari (dahulunya) bermata pencaharian sebagai nelayan dan petani rumput laut.
Berdasarkan sebaran jenis mata pencaharian responden diketahui juga bahwa pendapatan responden kurang dari Rp. 750.000 sebanyak $32,9 \%$, pendapatan antara Rp. 750.000 - Rp 999.000 sebanyak 31,5\%, pendapatan antara Rp. 1.000 .000 - Rp. 1.499 .000 sebanyak $21,9 \%$, pendapatan antara Rp. 1.500 .000 - Rp. 2.000 .000 sebanyak $8,2 \%$, dan pendapatan lebih dari Rp. 2.000 .000 sebesar 5,5\%. Bagi kelompok nelayan, besaran pendapatan sangat tergantung pada kondisi cuaca dan hasil tangkapan mereka di laut.

Observasi terhadap kondisi terumbu karang di bagian Utara Pulau Pari diketahui 
bahwa masih dalam kondisi baik dengan rerata kerapatan terumbu mencapai $8 \%$ saja.

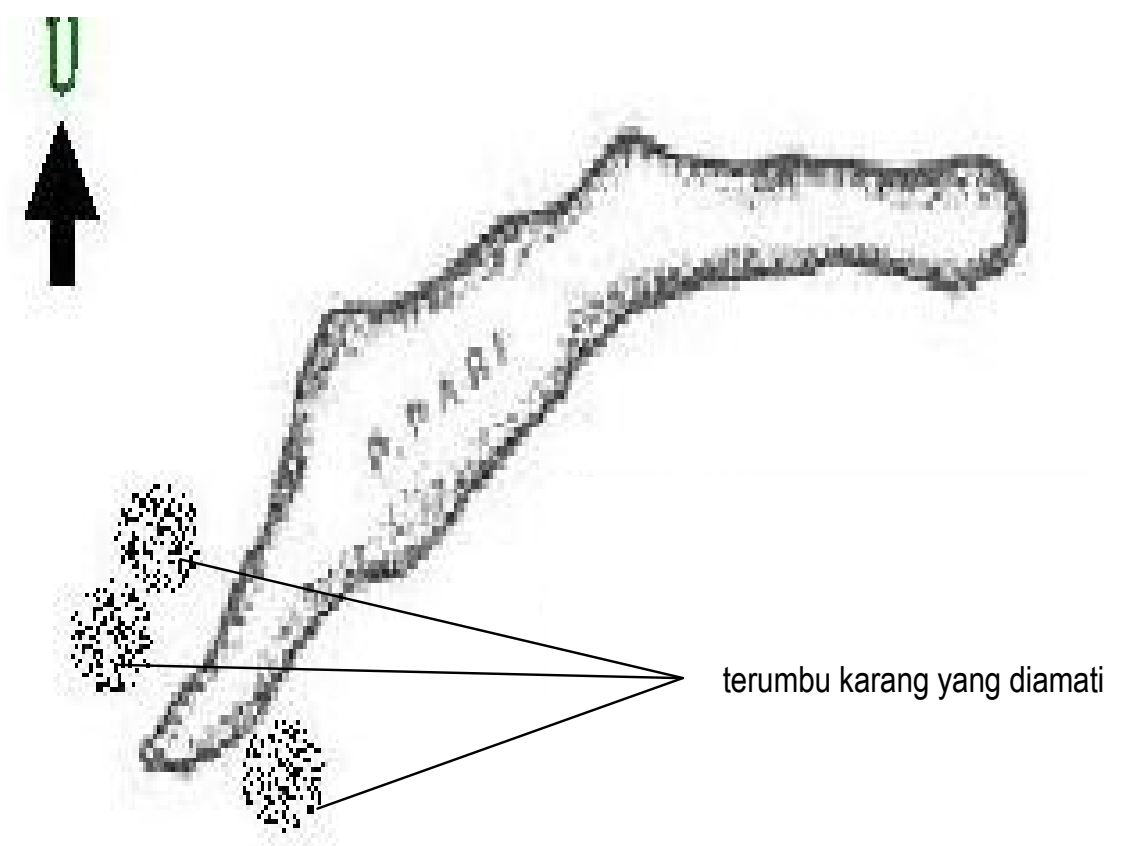

Gambar 1. Sebaran Terumbu Karang di Lokasi Penelitian

Dengan menggunakan metoda Line Intercept Transect (LIT), menunjukkan bahwa kondisi karang di Utara Pulau Pari berada pada kondisi sedang dengan tutupan karang hidup 41\% (non-Acropora 5\%, dan Acropora 36\%). Pada sisi Barat Pulau Tikus kondisi karang juga dalam dalam kondisi sedang dengan persentasi tutupan karang hidup 32\% (nonAcropora 2\% dan Acropora 30\%). Di sisi Selatan, kondisi karang berada pada sedang dengan tutupan karang hidup $50 \%$ yang seluruhnya didominasi oleh Acropora. Di sisi
Timur, kondisi karang hidup berada dalam kondisi baik dengan tutupan karang hidup $55 \%$. Ada kecenderungan bahwa pada sisi Timur kondisi karang membaik dengan tingkat tutupan karang yang menjadi lebih tinggi (meningkat dari 31\% menjadi sekitar 54\%).

Sementara itu, hasil observasi terumbu karang yang dilakukan di Pulau Pari Kudus (komunitas sosial setempat menyebutnya sebagai Pulau Joni) digambarkan sebagai berikut.

Tabel 2. Kerapatan Terumbu Karang di Utara Pulau Pari Kudus

\begin{tabular}{ccc}
\hline Titik & Azimut & Terumbu Karang \\
\hline 1 & $33^{\circ}$ (Timur Tenggara) & $5 / 25 \times 100 \%=20 \%$ \\
2 & $33^{\circ}$ & $9 / 25 \times 100 \%=36 \%$ \\
3 & $33^{\circ}$ & $3 / 25 \times 100 \%=12 \%$ \\
4 & $34^{\circ}$ & $2 / 25 \times 100 \%=8 \%$ \\
5 & $34^{\circ}$ & $10 / 25 \times 100 \%=40 \%$ \\
\hline \multicolumn{2}{c}{ Sumber: data lapang, 2013 }
\end{tabular}

Formulasi daftar kebutuhan (needs) dan keinginan (wants) masyarakat

Melalui metode analisis AHP (Analytical

Hierarchy Process), diketahui bahwa komunitas sosial lokal di lokasi penelitian menginginkan (secara urut/rangking) faktorfaktor berikut:

1. Adanya ketenangan

2. Penduduk dengan tingkah laku yang lebih berbudi-pekerti 
3. Kebersihan lingkungan

4. Keamanan baik di lingkungan permukiman, wisata, maupun tempattempat umum

5. Penduduk lokal dibekali pendidikan lingkungan terkaity upaya pelestarian lingkungan pulau

6. Upaya yang serius dari stakeholder pulau dan pemerintah terkait konservasi dan pengelolaan yang lebih baik terhadap sumberdaya

7. Adanya kontrol terhadap pertumbuhan penduduk dan pendatang (wisatawan maupun

8. Memiliki peraturan dalam pengelolaan perikanan secara baik dan dapat diterapkan

9. Konservasi budaya lokal yang lebih baik dan semakin berkembang

10. Kondisi lokasi pulau seperti keadaannya di masa lampau

11. Urbanisasi ke wilayah lain seperti kota Jakarta guna meningkatkan kesejahteraan keluarga di pulau.

Sementara itu, persepsi masyarakat tentang pengembangan yang tidak diinginkan di Pulau Pari tergambar bahwa demi terciptanya model penanganan kerusakan terumbu karang di perairan Kepulauan Seribu DKI Jakarta, maka terdapat kesamaan persepsi masyarakat pulau terhadap faktorfaktor yang tidak ingin terjadi (sebenarnya) seperti adanya kegiatan pembangunan (jalan, kendaraan, gedung hotel tinggi), aksentuasi pariwisata yang berlebihan, lokasi kawasan pulau dengan kondisi seperti sekarang (apa adanya), semakin banyaknya turis yang datang terutama di akhir pekan, meningkatnya pendatang dari luar pulau, bertambahnya jumlah penduduk yang terlalu tinggi, kegiatan parawisata / turis yang tidak teratur sehingga akan menyebabkan penurunan mutu lingkungan hidup di kawasan pulau serta kawasan perairan sekitar pulau, kegitan pembangunan yang tidak terencana dengan baik, lokasi yang kotor, datangnya orang jahat ke lokasi, serta munculnya masalah sosial (minuman keras, narkoba, pengangguran).

Roadmap analisis pengelolaan mediasi konflik sosial-ekonomi-pariwisata dalam penanganan kerusakan pantai

Upaya mediasi pada konflik sosialekonomi-pariwisata dalam penanganan kerusakan pantai di wilayah Kepulauan Seribu khususnya di Pulau Pari dan pulaupulau lain disekitarnya, maka harapan yang bisa diwujudkan diantaranya adalah:

1.Membentuk organisasi (lokal pulau dan luar pulau); Organisasi ini mengedepankan pendidikan konservasi laut. Salah satu tujuan dibentuknya wadah ini adalah untuk meningkatkan pemahaman dan pengetahuan bagi siswa akan pentingnya kelestarian lingkungan pesisir dan laut. Langkah ini dpandang tepat mengingat

2.Partisipasi wisatawan terhadap pelestarian terumbu karang; Wisatawan diajak secara bersama-sama (partisipatif) melakukan upaua pelestarian terumbu karang misalnya dengan kegiatan transplantasi karang buatan dan menanamnya di perairan. Program ini mengedepankan interaksi wisatawan terhadap lingkungan alam disertai belajar tentang ekosistem terumbu dan ikan karang.

3. Community empowerment; Interaksi wisatawan dengan masyarakat yang ada di sekitar pesisir sekaligus belajar mengenai kultur budaya masyarakat nelayan secara umum (lokasi kunjungan yang dijadikan sebagai tempat wisata, pendidikan pesisir dan laut, dan berinteraksi dengan kultur budaya masyarakat setempat).

\section{Model penanganan kerusakan terumbu} karang di Kepulauan Seribu DKI Jakarta

Fakta bahwa kondisi terumbu karang di perairan Pulau Pari masih dalam kondisi baik, merupakan modal penting di dalam upaya pengembalian habitat terumbu karang. Hal ini sangat mempengaruhi sistem mata pencaharian penduduk sebagai nelayan $(63,0 \%)$, sehingga memungkinkan adanya upaya untuk membangkitkan kesadaran warga dalam pelestarian terumbu karang, karena dengan masih adanya karang maka potensi perikanan lokal-pun tetap akan terjaga. 
Terkait meningkatnya perubahan lingkungan yang lebih disebabkan karena adanya faktor eksternal yaitu tingginya aktivitas wisata, cenderung akan diatasi melalui beberapa kesepakatan warga pulau melalui kesepahaman persepsi terhadap apa-apa yang diinginkan dan apa-apa yang tidak diinginkan. Sehingga upaya mediasi konflik lingkungan bisa dilakukan dengan memperhatikan aspekaspek ketenangan warga setempat, harapan terhadap tingkah laku yang lebih berbudi-pekerti, upaya peningkatan masalah kebersihan dan keamanan, rasa memiliki pendidikan lingkungan yang cukup tinggi, kesadaran warga terhadap pentingnya konservasi dan pengelolaan yang lebih baik terhadap sumberdaya, keinginan warga setempat terhadap kontrol pertumbuhan penduduk dan pendatang, adanya penegakkan aturan (hukum) lingkungan serta realisasi stakeholder dalam melaksanakan konservasi budaya yang lebih baik; sehingga lingkungan lokal mampu memperlihatkan kondisi lokasi seperti keadaannya di masa lampau namun dengan treatment lingkungan yang lebih baik misalnya dengan kegiatan wisata peduli lingkungan.

Formula mediasi konflik sosialekonomi-pariwisata dalam penanganan kerusakan pantai di Pulau Pari Kepulauan Seribu perlu memperhatikan tiga pilar utama yaitu organisasi (lokal pulau dan luar pulau), partisipasi wisatawan terhadap pelestarian terumbu karang, serta community empowerment bagi warga lokal, pendatang maupun para wisatawan.

Dengan demikian, upaya pengembangan model penanganan kerusakan terumbu karang di Kepulauan Seribu DKI Jakarta dan secara khusus di Pulau Pari, lebih ditekankan pada sapekaspek penguatan organisasi lokal yang semakin tangguh (empowering). Organisasi lokal ini tentunya dibangun atas dasar kesepahaman terhadap faktor-faktor perubahan yang diinginkan dan atau yang tidak diinginkan dan itu telah disepakati. Penguatan organisasi lokal tentunya harus memberikan teladan yang baik terhadap pendatang (wisatawan) terkait upaya pelestarian lingkungan pulau khususnya penyelamatan dan pelestarian terumbu karang.

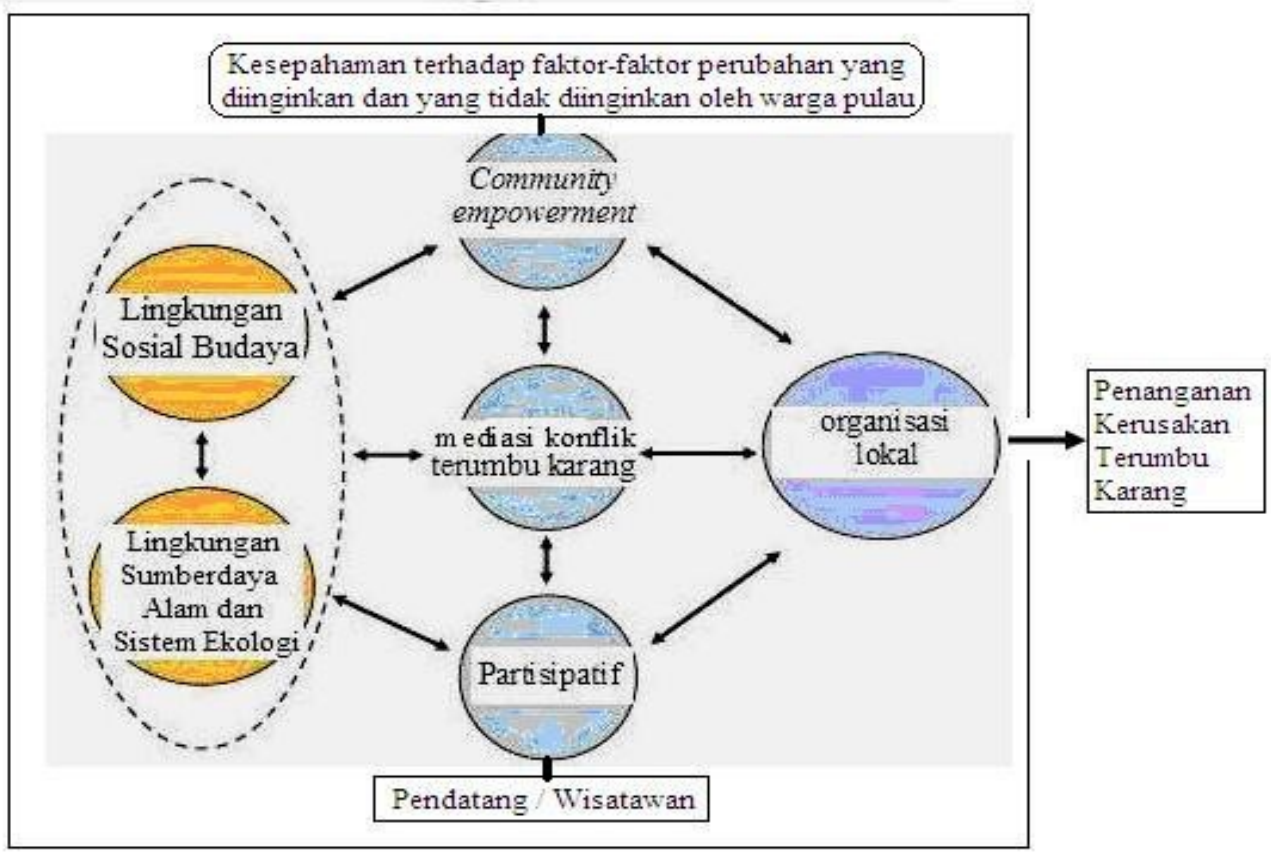

Gambar 2. Model Penanganan Kerusakan Terumbu Karang di Kepulauan Seribu DKI Jakarta 


\section{KESIMPULAN}

1.Bahwa kondisi terumbu karang di perairan Pulau Pari masih dalam kondisi baik, sehingga informasi ini bisa dijadikan modal penting di dalam upaya pengembalian habitat terumbu karang.

2.Masih dominannya mata pencaharian penduduk sebagai nelayan (63,0\%), sehingga usaha membangkitkan kesadaran warga dalam pelestarian terumbu karang, karena dengan masih adanya karang maka potensi perikanan lokal-pun tetap akan terjaga.

3.Upaya mediasi konflik lingkungan bisa dilakukan dengan memperhatikan aspekaspek ketenangan warga setempat, harapan terhadap tingkah laku yang lebih berbudipekerti, upaya peningkatan masalah kebersihan dan keamanan, rasa memiliki pendidikan lingkungan yang cukup tinggi, kesadaran warga terhadap pentingnya konservasi dan pengelolaan yang lebih baik terhadap sumberdaya, keinginan warga setempat terhadap kontrol pertumbuhan penduduk dan pendatang, adanya penegakkan aturan (hukum) lingkungan serta realisasi stakeholder dalam melaksanakan konservasi budaya yang lebih baik; sehingga lingkungan lokal mampu memperlihatkan kondisi lokasi seperti keadaannya di masa lampau namun dengan treatment lingkungan yang lebih baik misalnya dengan kegiatan wisata peduli lingkungan.

4.Formula mediasi konflik sosial-ekonomipariwisata dalam penanganan kerusakan pantai di Pulau Pari Kepulauan Seribu perlu memperhatikan tiga pilar utama yaitu organisasi (lokal pulau dan luar pulau), partisipasi wisatawan terhadap pelestarian terumbu karang, serta community empowerment bagi warga lokal, pendatang maupun para wisatawan.

5.Upaya pengembangan model penanganan kerusakan terumbu karang di Kepulauan Seribu DKI Jakarta dan secara khusus di Pulau Pari, lebih ditekankan pada aspekaspek penguatan organisasi lokal yang semakin tangguh (empowering). Organisasi lokal ini tentunya dibangun atas dasar kesepahaman terhadap faktor-faktor perubahan yang diinginkan dan atau yang tidak diinginkan dan itu telah disepakati. Penguatan organisasi lokal tentunya harus memberikan teladan yang baik terhadap pendatang (wisatawan) terkait upaya pelestarian lingkungan pulau khususnya penyelamatan dan pelestarian terumbu karang.

\section{DAFTAR PUSTAKA}

Bengen, D.G., 2002, Sinopsis Ekosistem Sumberdaya Alam Pesisir dan Laut serta Prinsip Pengelolaannya, Bogor, Pusat Kajian Sumberdaya Pesisir dan Lautan, Institut Pertanian Bogor.

Burke L., Selig E., Spalding M., 2002 Terumbu Karang Yang Terancam Di Asia Tenggara (Ringkasan untuk Indonesia), World Resources Institute, Amerika Serikat.

Coremap II, 2007, Pengenalan Karang Family Merulinidae, Buletin Coremap II Vol. 2, ISSN : 1907-7416, Jakarta.

Dahuri, R., 2003. Keanekragaman Hayati Laut, PT. Gramedia Pustaka Utama, Jakarta.

Dahuri, R., Rais J., Ginting S.P., Sitepu. M.J., 1996. Pengelolaan Sumber Daya Wilayah Pesisir dan Lautan Secara Terpadu, PT. Pradnya Paramita, Jakarta.

Darsono, Valentinus. 1995. Pengantar IImu Lingkungan. Yogyakarta: Universitas Atma Jaya.

Dinas Kelautan dan Perikanan Provinsi banten. 2089. Studi Pengembangan Lembaga Ekonomi Nelayan dan Masyarakat Pesisir.

Kaerudin dan Samadi. 2010. Analisis pergeseran mata pencaharian penduduk dan pengaruhnya terhadap ekosistem mangrove di pesisir Muara Angke Jakarta Utara. Laporan Penelitian Lembaga Penelitian Universitas Negeri Jakarta. Tidak Dipublikasikan.

Nybakken, James W. 1982. Biologi Laut; Suatu Pendekatan Ekologis. Jakarta: Gramedia.

Samadi. 2010. Daya dukung lingkungan dan pengaruhnya terhadap pariwisata berkelanjutan di pesisir Pangandaran Kabupaten Ciamis, Jawa Barat. Laporan 
Penelitian Fakultas IImu Sosial Universitas Negeri Jakarta. Tidak Dipublikasikan.

Samadi. 2011. Pengembangan Disain

Pendidikan Lingkungan untuk Ketahanan dan Sistem Sosial-Ekologis Terumbu Karang di Perairan Kepulauan Seribu DKI Jakarta. Laporan Penelitian Lembaga Penelitian Universitas Negeri Jakarta. Tidak Dipublikasikan.

Samadi. 2012. Model edukasi dan pariwisata bahari melalui teknologi karang buatan di Pulau Pari Kepulauan Seribu DKI Jakarta. Laporan Penelitian Lembaga Penelitian Universitas Negeri Jakarta. Tidak Dipublikasikan.
Samadi. 2012. Model rekayasa sosial untuk ketahanan dan sistem sosial-ekologis terumbu karang di kawasan Kepulauan Seribu DKI Jakarta. Laporan Penelitian Fakultas IImu Sosial Universitas Negeri Jakarta. Tidak Dipublikasikan.

Soemarwoto, Otto. 2001. Ekologi, Lingkungan Hidup dan Pembangunan. Jakarta: Djambatan.

Warnadi dan Samadi. 2009a. Roadmap Terumbu Karang dan Padang Lamun di Perairan Pulau-Pulau Pari Kabupaten Administratif Kepulauan Seribu DKI Jakarta. Laporan Penelitian Fakultas IImu Sosial Universitas Negeri Jakarta. Tidak Dipublikasikan. 